\title{
DETERMINATION OF POTASSIUM REQUIREMENT AND EFFECTS OF POTASSIUM FERTILIZATION ON GROWTH PARAMETERS OF HYPOESTES \\ (Hypoestes sanguinolenta)
}

\section{Ali íNAL ${ }^{1}$ M.Rüştü KARAMAN ${ }^{2}$ Dilara ERDEN ${ }^{1}$}

\begin{abstract}
Summary:, Hypoestes Hypoestes sanguinolenta were planted in PVC pots filled with perlite and irrigated with nutrient solutions of variable potassium contents. The height, fresh and dry weights and mineral composition of top and root and nutrient uptake were evaluated.

The results obtained showed that increase of the $\mathrm{K}$ level in the nutrient solution up to $100 \mathrm{ppm}$ increased the height of top and root, and growth. Above this level, they were affected adversely. Mineral composition of plants showed similar tendency to that of growth. Top and root height showed approximately three-fold an one and a half fold increase over to the control at $100 \mathrm{ppm} \mathrm{K}$ level reaching from 15.9-to $43.4 \mathrm{~cm}$ and 16.1-to $24.3 \mathrm{~cm}$ respectively for top and root. Fresh and dry weights increased from 3.17 to $18.96 ; 0.49$ to $2.49 \mathrm{~g}$ /pot for top and 1.92 to $6.19 ; 0.16$ to $0.50 \mathrm{~g} /$ pot for root respectively at the same $\mathrm{K}$ rates. While uptake and contents of $\mathrm{P}$ with $\mathrm{K}$ uptuke by both top and root increased up to $100 \mathrm{ppm} \mathrm{K}$ level, each increment of $\mathrm{K}$ in nutrient solution resulted in increasing in $\mathrm{K}$ concentration .
\end{abstract}

Key Words: Ornamental plants, Hypoestes, mineral composition, potassium

\section{POTASYUM GÜBRELEMESININ HIPOESTES Hypoestes sanguinolenta BITTKISİNIN GELIŞIMINE ETKISI VE POTASYUM GEREKSINIMININ BELIRLENMESI}

Özet: Serada, değişik oranlarda potasyum içeren besin çözeltisiyle perlit doldurulmuş plastik saksılarda Hipoestes Hypoestes sanguinolenta bitkisi yetiştirilerek, bitkinin tepe ve kök boyu, yaş ve kuru ağırlığı ile $N, P, K$ kapsamı ve bunların alınım miktarlan belirlenmiștir.

Elde edilen sonuçlara göre; 100 ppm $\mathrm{K}$ düzeyine kadar besin çözeltisindeki $\mathrm{K}$ konsantrasyonu arttıkça bitkinin tepe ve kök gelişimi ile boylan da artmıs ve 100 ppm K düzeyinden sonra olumsuz etkilenmiștir. Bitkinin mineral bileşimi de buna benzer değişim göstermiștir. Tepe ve kök boylanı sırasıyla kontrolde $15.9 \mathrm{~cm}$ den $100 \mathrm{ppm} \mathrm{K}$ düzeyinde $43.4 \mathrm{~cm}$ ve $16.1 \mathrm{~cm}$ den $24.3 \mathrm{~cm}$ ye yükselerek sırasıyla yaklaşık 3 ve 1.5 kat artış göstermişlerdir. Aynı K düzeylerinde tepe ve kök yaş ve kuru ağırlıkları ise sırasıyla 3.17-18.96; 0.49-2.49;1.92-6.19;0.16-0.50 g/saksı olarak gerçekleşmiştir. Tepe ve kökün $\mathrm{P}$ kapsamı ve $\mathrm{P}$ alımı ile $\mathrm{K}$ alımıl00 ppm $\mathrm{K}$ düzeyine kadar artıp sonra azalırken, bitkinin $\mathrm{K}$ kapsamı tüm $\mathrm{K}$ düzeylerinde artmıştır.

Anahtar Kelimeler: Süs bitkileri, Hypoestes, mineral kapsamı, potasyum

\section{Introduction}

Growing and selling of potted or cut flowers improves the economy of countries. Because the ornamentals give more net profit to the growers, farmers tend to grow flowers instead of vegetables. Turkey is known to be the motherland almost of all species of plants. Especially, Mediterranean region has the ecological conditions that enables many different varieties of plants to grow.

On the other hand, the more green areas getting smaller the more people wants to satisfy their missing to green areas by planting or growing flower plants.

Also, flowering plants is the rare material that reflects feelings of people on every conditions that reaches from sadness to happiness. That's why growers of flower plants has intensified their aims on quenching desires of customers. To grow flowers, good in market quality, is not always possible: ecological conditions, growth media and especially fertilization have important role in doing that.

The amount of mineral nutrients absorbed by flowering plants varies with the species and the season of cultivation. The cultivating conditions such as planting density, frequency of cutting flowers etc. also influence the mineral nutrients that are absorbed. The amount of $\mathrm{N}, \mathrm{P}_{2} \mathrm{O}_{5}, \mathrm{~K} 2 \mathrm{O}, \mathrm{CaO}, \mathrm{MgO}$ absorbed by cut flowers is 150 to $270 ; 30$ to $160 ; 130$ to $690 ; 60$ to 210 ; and 20 to $70 \mathrm{~kg} / \mathrm{ha}$ respectively. The variation in nutrient absorption among species is relatively small with $\mathrm{N}$ and large for $\mathrm{P}_{2} \mathrm{O}_{5}$ and $\mathrm{K}_{2} \mathrm{O}$ (Hosoya and Tokunaga 1978). 
Optimum yield, which is one objective of most crop production, is affected by the nutritional environment. The nutritional environment for plant roots has the same characterization as the soil solution phase to be absorbed by the plant. Potassium is an essential element and affects crop yield and quality; thus it must be provided by at the proper intensity and balance (Holcomb and White 1974).

Hosoya and Tokunaga (1978), reported that predicated on the average absorption amount of $\mathrm{N}$ for both cut and potted flowers being 100, the absorption ratios of $\mathrm{P}_{2} \mathrm{O}_{5}, \mathrm{~K}_{2} \mathrm{O}, \mathrm{CaO}, \mathrm{MgO}$ would be respectively equivalent to $35,168,82$ and 25 . This suggests that the absorption ratios of $\mathrm{K}_{2} \mathrm{O}$ and $\mathrm{MgO}$ are somewhat higher in flowers than in vegetables.

The purpose of this study was to determine the $\mathrm{K}$ requirement and the effects of $\mathrm{K}$ on growth parameters of Hypoestes.

\section{Material and Methods}

The experiment was carried out in cylindrical PVC pots with $400 \mathrm{~cm}^{3}$ volume that has a $1 \mathrm{~cm}$ drainage hole at the bottom and filled with perlite. Hypoestes Hypoestes sanguinolenta cuttings were grown in glasshouse for three months and received a balanced nutrient solution (Johnson et al 1957) of $\mathrm{pH} 6.50$ containing $0,20,50,100,200$ and $500 \mathrm{ppm} \mathrm{K}$ as $\mathrm{K}_{2} \mathrm{SO}_{4}$ and following in $\mathrm{g} / \mathrm{l}: 0.024 \mathrm{NH}_{4} \mathrm{NO}_{3} ; 0.945 \mathrm{Ca}\left(\mathrm{NO}_{3}\right)_{2}$ $4 \mathrm{H}_{2} \mathrm{O} ; 0.230 \mathrm{NH}_{4} \mathrm{H}_{2} \mathrm{PO}_{4} ; 0.246 \mathrm{MgSO}_{4}$ and in $\mathrm{mg} / \mathrm{l}$ : $2.93 \mathrm{NaCl} ; 1.55 \mathrm{H}_{3} \mathrm{BO}_{3} ; 0.34 \mathrm{MnSO}_{4} 7 \mathrm{H}_{2} \mathrm{O} ; 0.58$ $\mathrm{ZnSO}_{4} 7 \mathrm{H}_{2} \mathrm{O} ; 0.13 \mathrm{CuSO}_{4} 5 \mathrm{H}_{2} \mathrm{O} ; 0.08 \mathrm{H}_{2} \mathrm{MoO}_{4}(\% 85$ $\left.\mathrm{MoO}_{3}\right) ; 6.92 \mathrm{Fe}$-EDTA.

During the three months growing period, plants were watered with the above mentioned nutrient solution and at the end of the every week growth media of the plants were washed with water in order to prevent salt accumulation.

Six replications of the treatments were arranged in a complete-randomized design.

After three months from transplantation, the shoots and roots were seperated. After determining the fresh weights and heights, plants were washed and oven dried at $65-70{ }^{\circ} \mathrm{C}$ for dry weights and further analyses. Plants were wet-ashed with $\mathrm{HNO}_{3}$ and $\mathrm{HClO}_{4}$ for $\mathrm{P}$ and $\mathrm{K}$ analysis. Analysis included $\mathrm{P}$ (spectrometrically using molibdate method); $\mathrm{K}$ (by flamephotometer) and $\mathrm{N}$ (micro-Kjeldahl).

All data were statistically analyzed by using analysis of variance and treatment means were comparaed using Duncan's multiple range test $(p<0.05)$.

\section{Results and Discussion}

\section{Height, fresh weight and dry weight}

Effects of various levels of potassium in nutrient solution on growth parameters of Hypoestes were given in Table 1.

Fresh and dry weights of the top and root in the low $\mathrm{K}$ treatments were significantly lighter in weight than those in the high $\mathrm{K}$ treatments. Height of the top and root increased with increased levels of $K$ in nutrient solutions. Height, fresh and dry weight were apparently indicative measure of $\mathrm{K}$ supply. Up to the $100 \mathrm{ppm} \mathrm{K}$ rates, there was a linear increase in height, fresh and dry weight of the top and root with the concentration of $\mathrm{K}$ in fertilizer solution. Top height, fresh and dry weight increased by 173,498 and 400 percent respectively with increase of $\mathrm{K}$ from 0 to $100 \mathrm{ppm}$ while that of root's increased by 51,213 and 213 percent. Increases in top growth parameters always exceeded root growth parameters. In gravel culture $75 \mathrm{ppm} \mathrm{K}$ was apparently providing sufficient K (Joiner 1967). Similar observation about height, fresh and dry weight was also reported by Lunt and Kofranek (1958).

Suwanarit and Sestapukdee (1993) reported that $\mathrm{K}$ fertilization increased grain yield, stover yield. grainstover ratio and stimulated chlorophyll synthesis of maize. It has been reported that $\mathrm{N}, \mathrm{K}$ and $\mathrm{P}, \mathrm{K}$ fertilizer combinations resulted in an increase of weight of bulbs and best storage combinations of tulip (Doncheva 1975).

Table 1. Top and root height. fresh and dry weight of the experimental plants

\begin{tabular}{||c|c|c|c|c|c|c||}
\hline \multirow{2}{*}{$\begin{array}{c}\text { K(ppm)in } \\
\text { nutrient } \\
\text { solution }\end{array}$} & \multicolumn{3}{|c|}{ TOP } & \multicolumn{3}{c||}{ ROOT } \\
& \multicolumn{3}{|c|}{} & \multicolumn{2}{c||}{} \\
\cline { 2 - 7 } & $\begin{array}{c}\text { Height } \\
\mathrm{cm}\end{array}$ & $\begin{array}{c}\text { Fresh } \\
\text { weight } \\
\text { g/pot }\end{array}$ & $\begin{array}{c}\text { Dry } \\
\text { weight } \\
\text { g/pot }\end{array}$ & $\begin{array}{c}\text { Height } \\
\mathrm{cm}\end{array}$ & $\begin{array}{c}\text { Fresh } \\
\text { weight } \\
\text { g/pot }\end{array}$ & $\begin{array}{c}\text { Dry } \\
\text { weight } \\
\text { g/pot }\end{array}$ \\
\hline 0 & $15.88 \mathrm{~d}$ & $3.17 \mathrm{c}$ & $0.49 \mathrm{c}$ & $16.10 \mathrm{~b}$ & $1.92 \mathrm{c}$ & $0.16 \mathrm{c}$ \\
20 & $27.85 \mathrm{c}$ & $9.08 \mathrm{bc}$ & $1.27 \mathrm{bc}$ & $16.38 \mathrm{~b}$ & $3.53 \mathrm{~b}$ & $0.31 \mathrm{~b}$ \\
50 & $32.50 \mathrm{bc}$ & $12.48 \mathrm{~b}$ & $1.61 \mathrm{ab}$ & $16.65 \mathrm{~b}$ & $3.79 \mathrm{~b}$ & $0.33 \mathrm{~b}$ \\
100 & $43.42 \mathrm{a}$ & $18.96 \mathrm{a}$ & $2.45 \mathrm{a}$ & $24.33 \mathrm{a}$ & $6.00 \mathrm{a}$ & $0.50 \mathrm{a}$ \\
200 & $41.00 \mathrm{a}$ & $15.51 \mathrm{ab}$ & $2.04 \mathrm{ab}$ & $18.92 \mathrm{~b}$ & $4.88 \mathrm{ab}$ & $0.39 \mathrm{ab}$ \\
500 & $39.27 \mathrm{ab}$ & $11.95 \mathrm{~b}$ & $1.52 \mathrm{~b}$ & $17.83 \mathrm{~b}$ & $4.01 \mathrm{~b}$ & $0.32 \mathrm{~b}$ \\
\hline LSD \%5 & 7.34 & 6.03 & 0.84 & 3.16 & 1.28 & 0.12 \\
\hline
\end{tabular}


During the experiment, $\mathrm{K}$ deficiency symptoms, consisting of grazing and bronzing of the leaf underside at low level $\mathrm{K}$ rates $(0-50 \mathrm{ppm})$ was observed. This observation is in agreement with those reported by Hershey and Paul (1983). Woodson and Boodley (1982) reported that low $\mathrm{K}(1.0 \mathrm{meq} / \mathrm{l})$ limited the growth and flower production of greenhouse roses. The application of $\mathrm{P}$ and $\mathrm{K}$, and rising levels of each element tended to improve the flower spike quality, corm growth and cormel production of gladiolus.

\section{Nitrogen, phosphorus and potassium contents}

The results of $N, P, K$ analysis of the top and root of Hypoistes grown in perlite culture receiving fertilizer solution of varying $\mathrm{K}$ are shown in Table 2.

A perusal of the Table 2 indicates that the concentration of $\mathrm{K}$ was considerably and exponentially increased for both top and root correspondingly to the $\mathrm{K}$ rates in fertilizer solution. Top and root $\mathrm{K}$ concentration showing almost the same pattern increased by 327 percent with increase of $\mathrm{K}$ in nutrient solution and, top $\mathrm{K}$ concentration always surpassed root $\mathrm{K}$ concentration. At all levels of $\mathrm{K}$ added to nutrient solution, the highest amount of $\mathrm{K}$ content was observed in the treatment where $\mathrm{K}$ was added at $500 \mathrm{ppm}$ rate, whereas the lowest amount was observed in the control treatment. Increasing $\mathrm{K}$ concentration in nutrient solution caused $\mathrm{P}$ content of top to decrease and root $\mathrm{P}$ content to increase but this increase was not inconsistent. $\mathrm{N}$ content of both top and root decreased with increasing $\mathrm{K}$ rates in nutrient solution. Holcomb and White (1974) reported that the percentage of $\mathrm{N}, \mathrm{P}, \mathrm{Ca}$, and $\mathrm{Mg}$ decreased with increasing $\mathrm{K}$ in fertilizer solution. Results of present study and explanations find support in the work of Emmert (1961) and Joiner and Smith (1962). These authors also reported that increased substrate $K$ depressed foliar $\mathrm{P}$, and $\mathrm{K}$ was negatively correlated with $\mathrm{N}, \mathrm{P}, \mathrm{Ca}$ and $\mathrm{Mg}$.

\section{Nitrogen, phosphorus and potassium uptake}

Because uptake rate is the function of yield, except root $\mathrm{N}$ uptake, top and root $\mathrm{N}, \mathrm{P}, \mathrm{K}$ uptake increased almost exponentially with increasing $\mathrm{K}$ fertilizer in nutrient solution up to $100 \mathrm{ppm} \mathrm{K}$ rates (Table 3) showing any reduction. But root $\mathrm{N}$ uptake started to decrease at second $\mathrm{K}$ rate (ie. $50 \mathrm{ppm}$ ). Reduction in the uptake rates at 200 and $500 \mathrm{ppm} \mathrm{K}$ rates was found somewhat less significant than control.

Potassium fertilization increased top $\mathrm{N}$ and $\mathrm{P}$ uptake almost 4 times and $\mathrm{K}$ uptake 1.5 times. Root N, P and $\mathrm{K}$ uptake were increased by $\mathrm{K}$ treatmets $2,4,1$ times respectively. These results are in agreement with those of Hosoya and Tokunaga (1978).

Table 2. Top and root N, P, K contents of the experimental plants

\begin{tabular}{|c|c|c|c|c|c|c|}
\hline \multirow{2}{*}{$\begin{array}{c}\mathrm{K}(\mathrm{ppm}) \text { in } \\
\text { nutrient } \\
\text { solution }\end{array}$} & \multicolumn{3}{|c|}{ TOP } & \multicolumn{3}{|c|}{ ROOT } \\
\hline & $\begin{array}{l}\mathrm{N} \\
\%\end{array}$ & $\begin{array}{c}\mathrm{P} \\
\%\end{array}$ & $\begin{array}{l}\mathrm{K} \\
\%\end{array}$ & $\begin{array}{l}\mathrm{N} \\
\%\end{array}$ & $\begin{array}{l}\mathrm{P} \\
\%\end{array}$ & $\begin{array}{l}\mathrm{K} \\
\%\end{array}$ \\
\hline 0 & $8.01 \mathrm{a}$ & $0.57 \mathrm{a}$ & $1.78 \mathrm{f}$ & $5.24 \mathrm{a}$ & $0.57 c$ & $1.30 \mathrm{~d}$ \\
\hline 20 & $7.93 \mathrm{a}$ & $0.56 \mathrm{~b}$ & $2.97 \mathrm{e}$ & $4.82 \mathrm{ab}$ & $0.65 a b c$ & $1.97 \mathrm{~d}$ \\
\hline 50 & $7.28 \mathrm{a}$ & $0.54 \mathrm{c}$ & $4.12 \mathrm{~d}$ & $4.26 \mathrm{bc}$ & $0.63 b c$ & $3.52 \mathrm{c}$ \\
\hline 100) & $6.05 \mathrm{~b}$ & $0.45 \mathrm{e}$ & $5.24 \mathrm{c}$ & $3.57 \mathrm{c}$ & $0.67 \mathrm{ab}$ & $4.01 \mathrm{bc}$ \\
\hline 200) & $6.26 \mathrm{~b}$ & $0.51 \mathrm{~d}$ & $6.31 \mathrm{~b}$ & $4.11 \mathrm{bc}$ & $0.71 \mathrm{ab}$ & $5.05 \mathrm{ab}$ \\
\hline 500 & $6.03 \mathrm{~b}$ & $0.42 \mathrm{f}$ & $7.47 \mathrm{a}$ & $4.86 \mathrm{ab}$ & $0.75 \mathrm{a}$ & $5.35 \mathrm{a}$ \\
\hline LSD $\% 5$ & 0.76 & 0 & 0.30 & 0.76 & 0.09 & 1.10 \\
\hline
\end{tabular}

Table 3. Top and root N, P, K uptake of the experimental plants

\begin{tabular}{|c|c|c|c|c|c|c||}
\hline \multirow{2}{*}{$\begin{array}{c}\text { K(ppm)in } \\
\text { nutrient } \\
\text { solution }\end{array}$} & \multicolumn{3}{|c|}{ TOP } & \multicolumn{3}{c||}{ ROOT } \\
\cline { 2 - 7 } & $\mathrm{N} \mathrm{mg/pot}$ & $\mathrm{P} \mathrm{mg/pot}$ & $\mathrm{K} \mathrm{mg} / \mathrm{pot}$ & $\mathrm{N} \mathrm{mg} / \mathrm{pot}$ & $\mathrm{P}$ mg/pot & $\mathrm{K}$ mg/pot \\
\hline 0 & $38.59 \mathrm{c}$ & $2.80 \mathrm{c}$ & $8.87 \mathrm{~d}$ & $8.06 \mathrm{~b}$ & $0.88 \mathrm{c}$ & $1.97 \mathrm{c}$ \\
20 & $99.42 \mathrm{ab}$ & $7.06 \mathrm{abc}$ & $36.63 \mathrm{~cd}$ & $23.06 \mathrm{a}$ & $2.00 \mathrm{~b}$ & $6.07 \mathrm{c}$ \\
50 & $116.10 \mathrm{ab}$ & $8.53 \mathrm{ab}$ & $65.76 \mathrm{bc}$ & $14.26 \mathrm{ab}$ & $2.10 \mathrm{~b}$ & $11.97 \mathrm{~b}$ \\
100 & $148.50 \mathrm{a}$ & $11.19 \mathrm{a}$ & $128.29 \mathrm{a}$ & $17.94 \mathrm{a}$ & $3.39 \mathrm{a}$ & $19.91 \mathrm{a}$ \\
200 & $125.89 \mathrm{ab}$ & $10.25 \mathrm{ab}$ & $128.23 \mathrm{a}$ & $14.88 \mathrm{ab}$ & $2.73 \mathrm{ab}$ & $18.02 \mathrm{a}$ \\
500 & $90.37 \mathrm{bc}$ & $6.36 \mathrm{bc}$ & $113.59 \mathrm{ab}$ & $15.47 \mathrm{ab}$ & $2.40 \mathrm{~b}$ & $17.87 \mathrm{a}$ \\
\hline LSD \%5 & 52.41 & 4.16 & 49.55 & 8.26 & 0.84 & 4.75 \\
\hline
\end{tabular}




\section{References}

Doncheva, A., 1975. Effects of fertilizer application on the yield of tulip bulbs. Potash Review No. 3, subject 8 , bibliography 13 th suite, $p p 2$.

Emmert, F. H., 1961. The bearing of ion interactions on tissue analysis results. In Plant Analysis and Fertilizer Problems. Walter Reuther (Ed.). Amer. Inst. Biol. Sci.. Washington 6 D.C., p 231-243.

Hershey, D. R. and J. L. Paul, 1983. Some observations of potassium deficiency in chrysanthemum. Potash Review No. 3, subject 8, bibliography 20th suite, pp 1.

Holcomb, E. J. and J. W. White, 1974. Potassium fertilization of chrysanthemum using a constant-drip fertilizer solution. Plant and Soil 41: 271-278.

Hosoya, T. and Y. Tokunaga, 1978. Absorption pattern of mineral nutrients in cut and potted flowers of Japan. Potash Review No. 5, subject 8 , Fruit, vegetables and horticulture 31th suite, pp 1.

Johnson, C. M., P. R. Stout, T. C. Broyer, and A. B. Carlton, 1957.Comparative chlorine requirements different plant species. Plant and Soil 8: 337-353.
Joiner, J. N., 1967. Effects of P, $\mathbf{K}$ and $\mathrm{Mg}$ levels on growth, yield and chemical composition of chrysanthemum morifolium 'Indianapolis white \#3'. Proc. Am. Soc. Hort. Sci. 90: 389-396.

Joiner, J. N., and T. C. Smith, 1962. Effects of nitrogen and potassium levels on the growth, nowering responses and foliar composition of Chrysanthemum morifolium (Bluechip). Proc. Am. Soc. Hort. Sci., 80: 571-580.

Lunt, O. R. and A. M. Kofranek, 1958. Nitrogen and potassium nutrition of chrysanthemums. Proc. Amer. Soc. Hort. Sci. 72: 487-497.

Suwanarit, A. and M. Sestapukdee, 1993. Stimulating effects of foliar K-fertilizer applied at the appropriate stage of development of maize: $A$ new way to increase yield and improve quality. Potash Review No. 2, subject 6, bibliography 4th suite, pp 2 .

Woodson, W. R. and J. W. Boodley, 1982. Effects of nitrogen form and potassium concentration on growth, flowering and nitrogen utilization of greenhouse roses. J. Amer. Soc. Hort. Sci. 107(2): 275-278.

Eserin Kabul Tarihi : 18.08.1995 